\title{
Nuclear Receptor Coactivator 4
}

National Cancer Institute

\section{Source}

National Cancer Institute. Nuclear Receptor Coactivator 4. NCI Thesaurus. Code C19886.

Nuclear receptor coactivator 4 (579 aa, $66 \mathrm{kDa}$ ) is encoded by the human NCOA4 gene.

This protein plays a role in the modulation of androgen receptor-dependent gene transcription. 